\title{
Avtomatizacija procesov proizvajanja in nočno delo
}

\author{
Urška Kosem \\ Triglav, Zdravstvena zavarovalnica, d.d., Pristaniška ulica 10, 6000 Koper, Slovenija \\ urska.k8@gmail.com \\ Mirko Markič* \\ Univerza na Primorskem, Fakulteta za management, Cankarjeva 5, 6000 Koper, Slovenija \\ mirko.markic@fm-kp.si
}

\begin{abstract}
Povzetek:
Raziskovalno vprašanje (RV): Kakšna je povezanost stopnje avtomatizacije procesov proizvajanja in nočnega dela?

Namen: Opraviti empirično raziskavo o stopnji avtomatizacije procesov proizvajanja v večjih slovenskih proizvodnih podjetjih ter obsegu nočnega dela proizvodnih delavcev in ugotoviti, ali višja stopnja avtomatizacije pomeni manjši obseg nočnega dela oziroma ugotoviti, ali obstaja kakšna statistično značilna povezanost navedenih dejavnikov.

Metoda: Na vzorcu 116 srednje velikih ali velikih slovenskih podjetij z najmanj 50 zaposlenimi in $\mathrm{z}$ registrirano predelovalno dejavnostjo smo opravili kvantitativno raziskavo, s katero smo skozi pet skupin aktivnosti oziroma opravil v proizvodnem procesu izmerili in izračunali skupno oceno stopnje avtomatizacije celotnega proizvodnega sistema ter izmerili in primerjali število človek/ur proizvodnih delavcev, opravljenih v nočni izmeni, napram številu človek/ur proizvodnih delavcev, opravljenih v celotnem delovnem dnevu. Izračunano oceno stopnje avtomatizacije posameznega proizvodnega sistema smo primerjali $\mathrm{z}$ deležem nočnega dela glede na vse delo $\mathrm{v}$ dnevu ter izračunali Pearsonov koeficient korelacije.

Rezultati: Izračunana povezanost dejavnikov je negativna, kar sicer pomeni, da večja kot je stopnja avtomatizacije procesov proizvajanja, manj je nočnega dela, vendar gre za prenizko absolutno vrednost, da bi lahko govorili o statistično znatni povezanosti.

Organizacija: $\mathrm{V}$ povezavi $\mathrm{z}$ avtomatizacijo procesov proizvajanja smo predstavili vidike in elemente avtomatizacije, ki lahko pripomorejo k učinkovitejši uvedbi avtomatizacije procesov proizvajanja $\mathrm{v}$ organizaciji. V povezavi z nočnim delom smo predstavili argumente, zakaj je smiselno, da si vodstva organizacij omejevanje obsega nočnega dela zastavijo kot cilj, ter podali predloge, kako se zasledovanja tega cilja lahko lotijo.

Družba: Raziskava obravnava avtomatizacijo procesov proizvajanja kot potencialno rešitev za odpravo oziroma omejitev nočnega dela, ter vseh negativnih vplivov nočnega dela tako na delavca - posameznika, kot na njegov ožji in širši socialni krog. Na podlagi ugotovitev smo podali predloge, ki lahko pripomorejo k odpravi oziroma omejitvi nočnega dela in tako vplivajo na organizacijo delovnega časa in kakovost delovnega življenja posameznika.

Originalnost: Raziskava obravnava dva vsebinsko popolnoma nesorodna dejavnika, ki z vidika medsebojne povezanosti v dosedanjih raziskavah še nista bila obravnavana.

Omejitve/nadaljnje raziskovanje: Raziskave ni možno posplošiti na organizacije storitvenih dejavnosti, prav tako je ni možno posplošiti na aktivnosti v podjetjih z redistrirano predelovalno dejavnostjo, ki ne potekajo v okviru proizvodnega sistema. Raziskovanje avtomatizacije procesov in nočnega dela bi bilo koristno opraviti tudi $\mathrm{v}$ drugih dejavnostih, ki sicer niso proizvodno naravnane, a je kljub temu takšna oblika dela nujno potrebna in neizogibna, npr. v zdravstvu, trgovini, policiji, medijih, vojski ipd.
\end{abstract}

Ključne besede: menedžment, avtomatizacija, stopnja avtomatizacije, proces proizvajanja, nočno delo, nočna izmena, podjetja, proizvajanje, predelovalna dejavnost, raziskava. 


\section{Uvod}

Če se ozremo v preteklost in poglobimo v to, kako so si naši predniki v določenih obdobjih predstavljali prihodnost, naletimo na mnoge zanimive potencialne inovacije, za katere so ljudje takrat predvidevali, da se bodo nekoč pojavile tudi zares in narekovale popolnoma drugačen način življenja. Skupno večini ugibanj o prihodnosti je bilo, da bodo stroji prevzeli naše delo in bo življenje nasploh lažje in lepše. Stanje v današnji družbi pa izkazuje ravno nasprotno, namreč človek še nikoli ni bil toliko zaposlen kot danes in veliko zaslugo za to lahko pripišemo ravno tehnologiji.

Človek je začel delati, kadar je lahko - tudi ponoči. Nočnemu delu se v mnogih situacijah ne moremo izogniti. Brez policije, gasilcev, reševalcev, zdravstvenih delavcev in podobnih služb, ki so v pripravljenosti tudi ponoči, si življenja ne moremo predstavljati, po drugi strani pa ponoči delajo tudi mnogi delavci $v$ dejavnostih, npr. industrijski proizvodnji, za katero nočno delo v preteklosti ni bilo značilno.

Medtem ko imamo na eni strani tehnologijo, ki je napredovala do te mere, da lahko samodejno in samostojno opravlja delo namesto človeka, imamo na drugi strani delavce, ki se odpravijo na delo tudi ponoči. Čeprav je v praksi že možno zaznati namigovanja na povezanost avtomatizacije in zmanjšanja obsega nočnega dela, pa ta povezanost doslej še ni bila preučevana skozi strokovno in znanstveno literaturo. Ugotovili smo, da ni znanja in vednosti o povezanosti stopnje avtomatizacije ter zmanjšanja obsega ur nočnega dela.

Vodilo v naši raziskavi bo zato analizirati, ali lahko vsaj v dejavnostih proizvajanja, v katerih nočno delo ni nujno $z$ vidika delovanja družbe, tehnologijo izkoristimo delavcu v prid tako, da zmanjšamo obseg nočnega dela. V okviru tehnologije se bomo osredinili na avtomatizacijo procesov proizvajanja, za katero bomo poskusili ugotoviti, ali nosi potencial zmanjšanja obsega nočnega dela.

\section{Teoretična izhodišča}

S pojmom avtomatizacije ponazarjamo proces, v katerem naj bi tehnologija oz. stroji izvajali določene naloge, ki jih je prvotno ročno izvajal človek (Parasuraman \& Riley, 1997, str. 231). Natančneje je avtomatizacija (Šuman, 2016, str. 7): “Izvajanje procesa s točno določenimi koraki, kombiniranimi s povratnimi informacijami, da se zagotovi pravilna izvedba navodil. Rezultat tega je sistem, ki je sposoben za delovanje brez človekovega posega." Izraz se uporablja v sklopu različnih dejavnosti, kot so letalska, avtomobilska, medicinska, robotska in transportna (Parasuraman \& Riley, 1997, str. 230-231). Prednosti avtomatizacije proizvajanja, se odražajo $\mathrm{v}$ večji produktivnosti, boljši izkoriščenosti zmogljivosti, višji kakovosti proizvodov ali procesov, večjem izkoristku vhodnih surovin, nižjih stroških na enoto proizvoda ter boljših in varnejših delovnih pogojih (Sever, 2011, str. 15). 
Avtomatizacija naj bi nosila potencial prestrukturiranja velike večine obstoječih delovnih mest in posledično celotnih delovnih procesov (Chui, Manyika \& Miremadi, 2015, str. 5). Tveganju za avtomatizacijo so najbolj podvržene fizične aktivnosti, ki so predvidljive, ter kognitivne aktivnosti, kot npr. zbiranje in obdelava podatkov, ljudje pa so $\mathrm{v}$ teh primerih postavljeni $\mathrm{v}$ vlogo dopolnjevanja teh aktivnosti na način, da se omogoči celovita izvedba postopkov (Manyika et al., 2017, str. 2). Napredek tehnologije in avtomatizacija procesov sta zaslužna za trend izginjanja nezahtevnih srednje plačanih delovnih mest ter za pojav novih, zahtevnejših in bolje plačanih zaposlitev (Rotman, 2013, str. 30).

V okviru proizvajanja se $\mathrm{v}$ zvezi s pojavom avtomatizacije proizvajanja omenja tudi izraz lights-out avtomatizacija oz. lights-out proizvajanje. Podobno kot pri splošni definiciji avtomatizacije gre za tehnologijo, zasnovano z namenom, da do neke mere z njo opravljamo delo namesto delavca (Brann, Thurman \& Mitchell, 1996, str. 1). Stroji so nastavljeni in opremljeni tako, da za določen čas delo opravljajo avtonomno, brez prisotnosti in nadzora delavcev (Noël, Sodhi \& Lamond, 2007).

Kot prednost lights-out proizvodnih sistemov se v literaturi omenja možnost proizvajati ponoči brez navzočnosti človeka, kar pomeni prihranke pri stroških energije in dela, delavci pa se čez dan tako lahko posvetijo zapletenejšim nalogam (Eddy, 2013). Izpostavljajo potencial avtomatizacije nočne izmene kot strateške poteze v proizvajanju (Wolfgang et al., 2017, str. 4), predlagajo delitev proizvajanja na dve izmeni: na dnevno, ki bi bila namenjena delavcem, ter na nočno, ki bi jo opravljali zgolj roboti. Löfving et al. (2018, str. 180-183) ugotavljajo, da se vse bolj pojavljajo zahteve po tehnoloških rešitvah, ki omogočajo neprekinjen potek procesa proizvajanja brez človeške intervencije vsaj eno celotno izmeno.

Kljub temu, da so se že v prejšnjem stoletju v dejavnostih proizvajanja pojavljale težnje $\mathrm{k}$ uvedbi tovarn s popolno avtomatizacijo procesov proizvajanja, pa je večina naprednejših obratov proizvajanja zgolj delno avtomatizirana, kombinacija avtomatiziranih in ročnih opravil (Frohm, 2008, str. 2).

Za razlikovanje med bolj in manj avtomatiziranimi tovarnami, sistemi, procesi, opravili ipd. poznamo izraz stopnja avtomatizacije (angl. level of automation oz. LoA). Gre za porazdelitev fizičnih in kognitivnih opravil med človekom in tehnologijo, ki jo identificiramo kot stopnjo na lestvici od popolne neavtomatizacije do popolne avtomatizacije (Fasth, Stahre \& Dencker, 2008, str. 169). Medtem ko se v nekateri literaturi omenja zgolj tristopenjska lestvica $\mathrm{z}$ navedenima skrajnostma in eno vmesno stopnjo, tj. delna avtomatizacija, obstajajo tudi podrobneje definirane lestvice, npr. 10-stopenjska lestvica avtorjev Sheridan \& Verplanck (1978), ki kot najnižjo stopnjo nista opredelila popolne odsotnosti avtomatizacije, temveč že določeno mero sodelovanja človeka in računalnika oz. tehnologije.

Razvoj tehnike in tehnologije skozi čas je na človekovo delovno okolje vplival na različne načine. Ena izmed sprememb, ki jih je prinesel tehnološki razvoj, je uporaba umetne razsvetljave, ki je omogočila, da so ljudje svoje sicer dnevne aktivnosti začeli izvajati tudi 
ponoči. Ena izmed njih je bila tudi delo, kar je prineslo izmensko oz. nočno delo (Pustovrh, 2015, str. 3). Izmensko in nočno delo je v Republiki Sloveniji opredeljeno v Zakonu o delovnih razmerjih (ZDR) ter posredno še $\mathrm{v}$ nekaterih drugih zakonskih in podzakonskih aktih, na mednarodni ravni pa oblike del ureja tudi Konvencija Mednarodne organizacije dela (MOD) ter razni akti Evropske unije in Sveta Evrope (Vetter, 2015, str. 10-12).

Definicija nočnega dela se po prvem odstavku 150. člena Zakona o delovnih razmerih (ZDR) glasi (ZDR-1, 2013):

Kot nočno delo se šteje delo $\mathrm{v}$ času med 23. in šesto uro naslednjega dne. Če je $\mathrm{z}$ razporeditvijo delovnega časa določena nočna delovna izmena, se šteje za nočno delo osem nepretrganih ur v času med 22. in sedmo uro naslednjega dne.

Vzrok za odreditev nočnega dela je vrsta panoge, kjer je potrebna 24-urna prisotnost delavca na delovnem mestu, ali vrsta delovnega procesa, ki poteka neprekinjeno (Dobrin, 1992). Nočno delo se najpogosteje pojavlja v zdravstveni panogi, industrijski proizvodnji, rudarstvu, transportu, komunikacijski panogi in gostinsko-turistični panogi (Straif et al., 2007, str. 1065). Izmensko delo, še posebej delo $\mathrm{v}$ nočnih izmenah, se pogosto povezuje $\mathrm{z}$ raznimi zdravstvenimi težavami. Različne študije so dokazale, da obstaja tesna povezanost izmenskega dela s pojavnostjo raznih bolezni in zdravstvenih motenj (Scott \& LaDou, 1994; Knutsson, 2003, str. 104-105), pa tudi s težavami pri razmnoževanju (Costa et al., $2004 \mathrm{v}$ Mengeot, 2009, str. 14-15; Ahlborg, Axelsson \& Bodin, 1996, str. 788). Takšna oblika dela se povezuje tudi s pogostostjo nezgod na delu (Costa, 1996, str. 12). Nočno delo je zahtevnejša oblika dela, zato delavcu pripadajo posebne pravice in nadomestila (Dobrin, 1992). Thierry (1981 v Knauth et al., 1983, str. 372) ugotavlja, da je namesto plačnega nadomestila za nevšečnosti, ki nastanejo ob izmenskem delu, primerneje omejiti oz. odpraviti vzrok zanje, torej izmensko delo.

V določenih organizacijah po svetu so to že uspešno uresničili. Primer je univerzitetni klinični center v Nagoji na Japonskem, kjer so za dobavo zdravil in drugih materialov znotraj bolnišnice $\mathrm{v}$ nočnem času uvedli robote, ki so zaslužni za zmanjšanje potreb po kadru, natančneje medicinskih sestrah (Tsukidate, 2018). Podobno so naredili v enemu od tokijskih gradbenih podjetij, v katerem so zaradi pomanjkanja kadra zaposlili robote, ki pa zaradi varnosti delavcev delo opravljajo sami in samo ponoči (New York Post, 2018). Z nadgradnjo tehnologije so nočno izmeno omejili tudi v Hidroelektrarni Sava, kjer so uvedli delno avtomatizacijo določenih procesov in nadzorni sistem, s čimer so dosegli, da ob zmernih vremenskih razmerah delavci ponoči in ob koncu tedna niso več potrebni (Gorenjske elektrarne, 2014). V izogib uvedbi nočne izmene so v finski tovarni smetarskih tovornjakov zaradi povečanega povpraševanja uvedli robota za varjenje in obvladovanje težkih bremen, ki samostojno opravlja delo v nočni izmeni, medtem ko je čez dan naloga delavcev, da pripravijo vse potrebno za delovanje robota ponoči (Fanuc, 2018, str. 2-3).

Avtomatizacija procesov proizvajanja se v slovenskih empiričnih raziskavah omenja kot 
odgovor na pritiske globalnih trgov in posledično nenehne težnje k povečanju učinkovitosti in znižanju stroškov, in sicer z vidika vpeljave vitkega proizvajanja (Vrčkovnik, 2008, str. 5) ali metode PAT (procesna analitska tehnologija), ki je značilnejša za farmacevtsko industrijo (Vimpolšek, 2016, str. 32, 65). Vezano na strahove ljudi, da bosta razvijajoča se tehnologija in avtomatizacija procesov proizvajanja nadomestili človekovo delo in povzročili brezposelnost, Hundrič (2017, str. 70) ugotavlja, da v praksi to ne pomeni vedno zmanjšanja števila delovnih mest, temveč prestrukturiranje v manj monotona, zaradi česar se spreminjata tudi miselnost in odnos ljudi do tehnologije. Delež ur proizvodnih delavcev, opravljenih v nočni izmeni, pa se v slovenskih raziskovalnih nalogah omenja v sklopu negativnih učinkov na zdravje delavca, kot je stres (Goranski, 2011, str. 70). Izmenski oz. nočni delavci pogosteje navajajo motnje spanca, koncentracije in učenja ter razne zdravstvene in duševne težave (Korelič, 2017, str. 47). Novak (2016, str. 87) ugotavlja, da je izmensko delo, vključno z nočnim, družini neprijazna oblika dela, saj je v primeru take oblike razporeditve delovnega časa precej težje usklajevati delovno in zasebno življenje.

Na podlagi ugotovitev iz teoretičnih in empiričnih spoznanj smo formirali naslednji hipotezo:

Med stopnjo avtomatizacije procesov proizvajanja in deležem ur proizvodnih delavcev, opravljenih v nočni izmeni, obstaja negativna povezanost (višja kot je stopnja avtomatizacije, manj je nočnega dela).

\section{Metoda}

S ciljem ugotoviti, ali med stopnjo avtomatizacije procesov proizvajanja in obsegom nočnega dela proizvodnih delavcev obstaja povezanost ali ne, smo izvedli kvantitativno raziskavo, v okviru katere smo primarne podatke zbirali s pomočjo anketnega vprašalnika.

Kot kriterije populacije smo določili, da so enote srednje velika in velika industrijska podjetja v Sloveniji oz. natančneje slovenska podjetja z registrirano predelovalno dejavnostjo (C) po standardni klasifikaciji dejavnosti (SKD), in zaposlujejo vsaj 50 ljudi. Po zadnjih podatkih podatkovne baze Gvin je bilo na dan 27. 5. 2019 v Sloveniji registriranih 381 srednje velikih in 135 velikih aktivnih podjetij z registrirano predelovalno dejavnostjo (Gvin.com, 2019). Iz tega nabora smo izločili 14 podjetij, za katera smo lahko na podlagi javno dostopnih podatkov ugotovili, da nimajo aktivne proizvodnje in/ali v podjetju zaposlujejo manj kot 50 ljudi. Celotno populacijo in hkrati tudi ciljni vzorec - vprašalnik smo namreč posredovali vsem enotam iz populacije - nam torej predstavljata 502 veliki in srednje veliki podjetji predelovalne dejavnosti v Sloveniji z vsaj 50 zaposlenimi.

Vprašalnik je bil zasnovan na način, da je pri podjetjih, ki izvajajo nočno izmeno, lahko ugotovili razloge za izvajanje le-te in izmerili obseg dnevnega in nočnega dela ter stopnjo avtomatizacije $\mathrm{v}$ proizvodnem sistemu. Natančneje smo z ocenjevalno lestvico od 1 (popolnoma ročno) do 5 (popolnoma avtomatizirano) ugotavljali stopnjo avtomatizacije procesov proizvajanja glede na pet (5) različnih vrst operacij oz. opravil v proizvodnem 
sistemu po Ljubiču (2000, 3-4) in Kaltnekarju (1996, 13). To so (1) obdelava, (2) transport, (3) skladiščenje, (4) kontrola in vodenje ter (5) zastoj. V zadnjem delu vprašalnika smo vsa sodelujoča podjetja povprašali po nekaterih demografskih informacijah, kot sta dejavnost in število zaposlenih znotraj procesa proizvajanja.

Zbrane podatke smo nato obdelali in jih ovrednotili tako, da smo na pridobljenih osnovnih demografskih podatkih, vezanih na podjetje, opravili osnovno statistično analizo, za podatke, vezane na stopnjo avtomatizacije posameznih aktivnosti ter obseg dela, pa smo na podlagi teoretičnih ugotovitev razvili lastno metodologijo, s pomočjo katere smo te podatke ovrednotili ter jih obdelali na način, da smo pridobili skupno oceno stopnje avtomatizacije celotnega proizvodnega sistema posamezne enote.

Natančneje smo za pridobitev skupne ocene stopnje avtomatizacije procesov proizvajanja v posameznem sistemu ocenam na ravni aktivnosti kot utež dodelili koeficient razmerja človekovega dela pri tej aktivnosti glede na človekovo delo v celotnem proizvodnem sistemu in šele nato izračunali skupno oceno. Pri tem smo v obzir vzeli osnovno definicijo avtomatizacije, ki je - povzeto iz pregledane literature - zamenjava opravil, ki jih izvaja človek, z opravili, ki jih izvaja stroj. Tako smo ocenam aktivnosti, za katere potrebujemo več človekovega dela, dodelili večjo težo kot tistim, za katere ga potrebujemo manj, saj lahko logično sklepamo, da je bila za doseganje določene stopnje avtomatizacije ob trenutno večjem obsegu človekovega dela potrebna obsežnejša uvedba avtomatizacije, kot za doseganje iste stopnje pri trenutno manjšem obsegu dela. Če izračun poenostavimo in posplošimo, lahko zapišemo enačbo na sliki 1 .

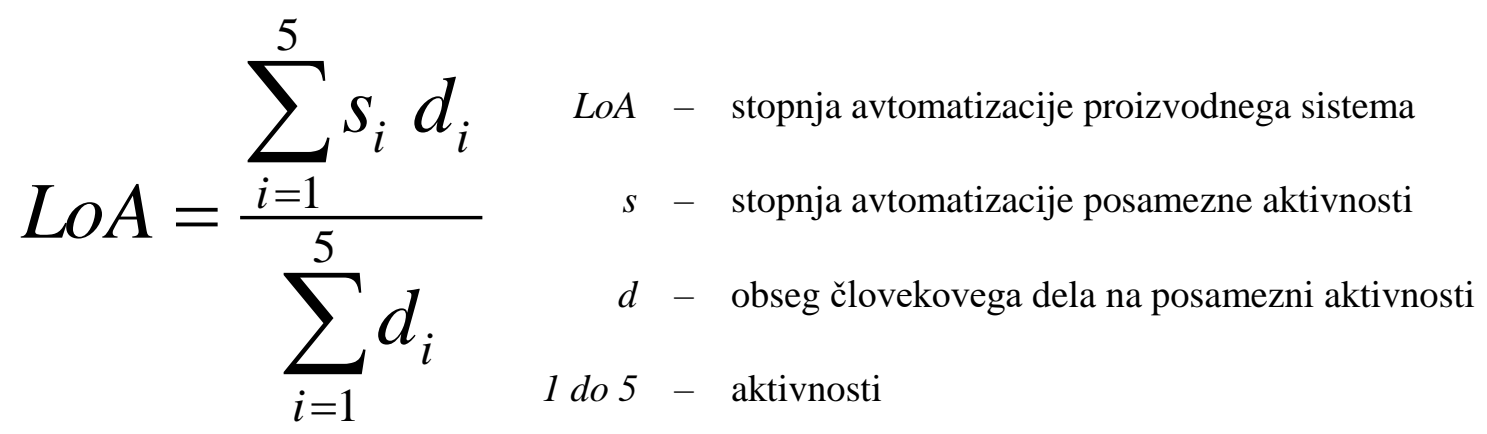

Slika 1. Izračun stopnje avtomatizacije

Pridobljene ocene stopenj avtomatizacije celotnih proizvodnih sistemov smo nato z uporabo metode Pearsonovega koeficienta korelacije primerjali z deležem ur proizvodnih delavcev, opravljenih v nočni izmeni glede na vse delo v dnevu, s čimer smo ugotavljali morebitno povezanost avtomatizacije in obsega nočnega dela. 


\section{Rezultati in razprava}

$\mathrm{V}$ tabeli 1 so prikazani rezultati raziskave, vezani na osnovne podatke o anketiranih podjetjih, to so izvajanje nočne izmene, število zaposlenih v proizvodnem sistemu in dejavnost.

Tabela 1. Število podjetij glede na različne lastnosti

\begin{tabular}{|c|c|c|}
\hline & Frekvenca & Delež (v \%) \\
\hline \multicolumn{3}{|l|}{ Izvajanje nočne izmene } \\
\hline $\mathrm{Da}$ & 79 & 68,10 \\
\hline $\mathrm{Ne}$ & 37 & 31,90 \\
\hline Skupaj & 116 & 100,00 \\
\hline \multicolumn{3}{|l|}{ Število zaposlenih v proizvodnem sistemu } \\
\hline $0-249$ & 61 & 52,59 \\
\hline $250-499$ & 12 & 10,34 \\
\hline $500-749$ & 2 & 1,72 \\
\hline $750-999$ & 2 & 1,72 \\
\hline $1000-1249$ & 1 & 0,86 \\
\hline $1250-1500$ & 1 & 0,86 \\
\hline brez odgovora & 37 & 31,90 \\
\hline Skupaj & 116 & 100,00 \\
\hline \multicolumn{3}{|l|}{ Dejavnost } \\
\hline C25 Proizvodnja kovinskih izdelkov, razen strojev in naprav & 16 & 13,79 \\
\hline C22 Proizvodnja izdelkov iz gume in plastičnih mas & 10 & 8,62 \\
\hline C23 Proizvodnja nekovinskih mineralnih izdelkov & 10 & 8,62 \\
\hline C10 Proizvodnja živil & 7 & 6,03 \\
\hline C27 Proizvodnja električnih naprav & 5 & 4,31 \\
\hline C24 Proizvodnja kovin & 4 & 3,45 \\
\hline C28 Proizvodnja drugih strojev in naprav & 4 & 3,45 \\
\hline C20 Proizvodnja kemikalij, kemičnih izdelkov & 3 & 2,59 \\
\hline C17 Proizvodnja papirja in izdelkov iz papirja & 2 & 1,72 \\
\hline C29 Proizvodnja motornih vozil, prikolic in polprikolic & 2 & 1,72 \\
\hline C13 Proizvodnja tekstilij & 1 & 0,86 \\
\hline C15 Proizvodnja usnja, usnjenih in sorodnih izdelkov & 1 & 0,86 \\
\hline C18 Tiskarstvo in razmnoževanje posnetih nosilcev zapisa & 1 & 0,86 \\
\hline C30 Proizvodnja drugih vozil in plovil & 1 & 0,86 \\
\hline C32 Druge raznovrstne predelovalne dejavnosti & 1 & 0,86 \\
\hline C33 Popravila in montaža strojev in naprav & 1 & 0,86 \\
\hline ni možno določiti & 10 & 8,62 \\
\hline brez odgovora & 37 & 31,9 \\
\hline Skupaj & 116 & 100,00 \\
\hline
\end{tabular}

Izmed vseh anketiranih podjetij sta dobri dve tretjini (79 podjetij) odgovorili, da v svojem proizvodnem sistemu izvajata nočno izmeno.

Anketirana podjetja imajo v svojih proizvodnih sistemih v povprečju 185,6 zaposlenih, pri 
čemer podjetje $\mathrm{z}$ najmanj zaposlenimi v proizvodnem sistemu zaposluje 17 ljudi, podjetje $\mathrm{z}$ največ pa 1.305 . Če iz izračuna izvzamemo 37 enot, za katere nismo pridobili odgovora oz. podatka, se večina podjetij, tj. 77,22 \%, uvršča v prvi razred po številu zaposlenih, in sicer v razred od 0 do vključno 249 zaposlenih. V drugi razred do vključno 499 zaposlenih se jih uvršča $15,19 \%$, v preostale razrede do 1500 zaposlenih pa skupno le 7,59 \% podjetij.

Prvih pet dejavnosti, s katerimi se ukvarja največ podjetij iz vzorca (37 anketirancev odgovora ni podalo), je:

1. C25 proizvodnja kovinskih izdelkov, razen strojev in naprav,

2. C22 proizvodnja izdelkov iz gume in plastičnih mas,

3. C23 proizvodnja nekovinskih mineralnih izdelkov,

4. C10 proizvodnja živil in

5. C27 proizvodnja električnih naprav.

Preostalih deset predelovalnih dejavnosti, ki so se pojavile med navedbami anketirancev, skupaj predstavlja $26 \%$ celotne strukture, medtem ko za $13 \%$ navedb zaradi preveč splošnih odgovorov (npr. »proizvodnja«, »montaža«) dejavnosti glede na SKD nismo mogli opredeliti.

Če se vrnemo na podatek o izvajanju nočne izmene in ga primerjamo s številom zaposlenih, dobimo naskednji diagram razpršenosti podatkov, iz katerega je razvidno, da se nočna izmena pogosteje pojavlja v podjetjih $\mathrm{z}$ več zaposlenimi v proizvodnem sistemu.

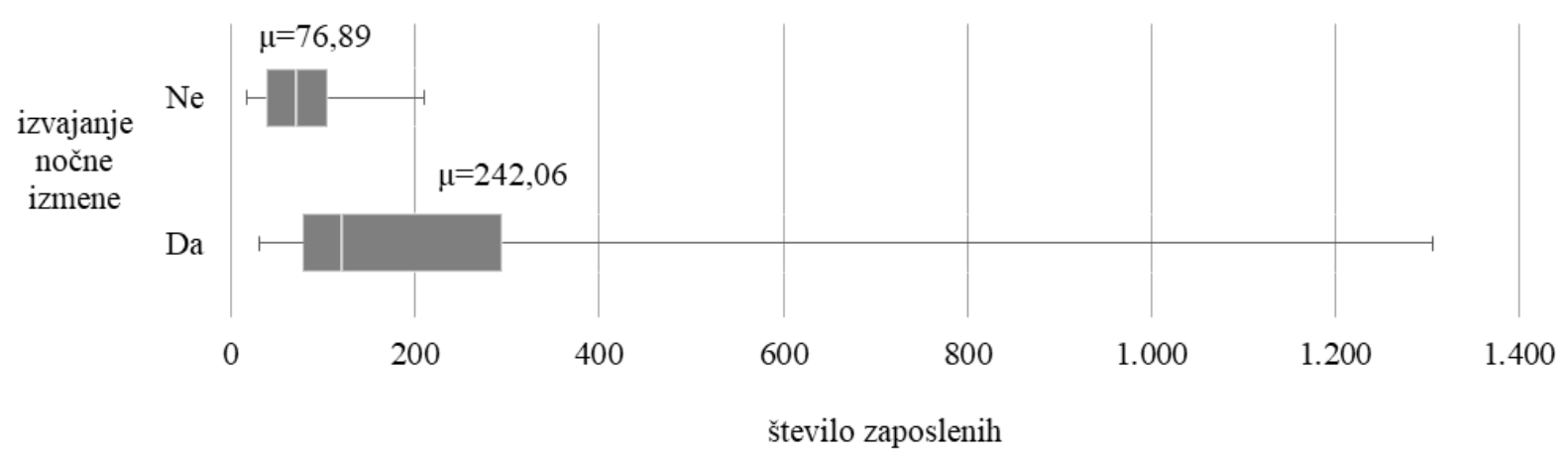

Slika 2. Izvajanje nočne izmene glede na število zaposlenih $(\mathrm{n}=79)$

Podjetja z nočno izmeno smo povprašali o razlogih za njeno izvedbo oz. zakaj je v njihovem sistemu potrebna. Vprašanje je bilo odprtega tipa, prejete odgovore pa smo naknadno v osnovi razporedili $\mathrm{v}$ tri skupine, to so ekonomski, tehnološki in organizacijski razlogi, dodatno pa smo bili primorani opredeliti še četrto skupino za vse odgovore, ki niso bili podani dovolj natančno, da bi jih lahko dodelili eni od prej naštetih skupin (npr. »narava dela«, »specifike«). Kljub temu je bilo iz preostalih odgovorov možno jasno razbrati, da v predelovalni dejavnosti prevladujejo ekonomski razlogi za izvajanje nočne izmene, najredkeje pa se pojavljajo organizacijski. Na naslednjem diagramu na sliki 3 so ponazorjene pojavnosti posameznih razlogov za uvedbo nočnega dela v proizvodnih sistemih, iz prikaza pa so izvzeti 
štirje anketiranci, ki so odgovorili, da izvajajo nočno izmeno, niso pa podali razloga.

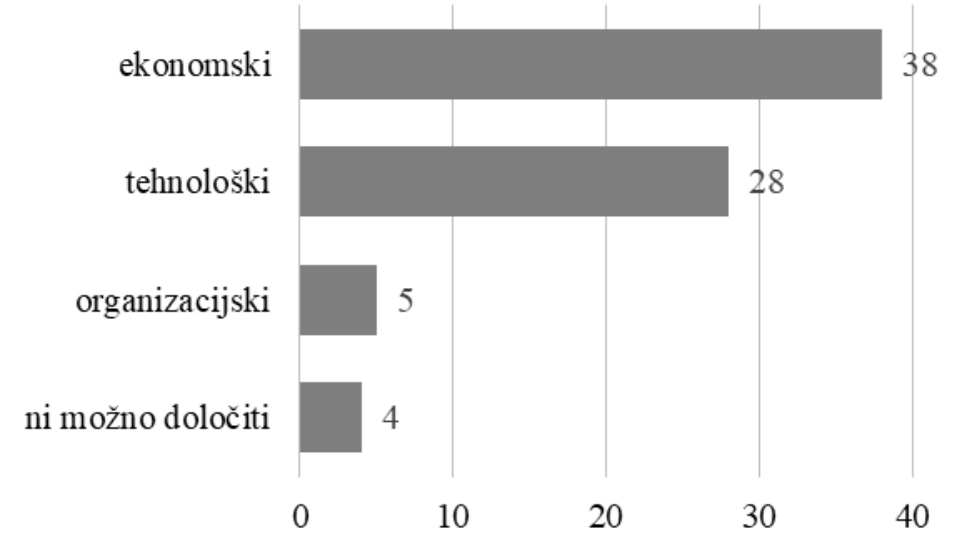

Slika 3. Razlogi za izvajanje nočne izmene $(\mathrm{n}=75)$

Med ekonomskimi razlogi so se največkrat pojavljale navedbe, kot so izkoriščenost zmogljivosti, povečanje naročil in zahteve odjemalcev ter izraba drage proizvodne opreme oz. strojev. Med tehnološkimi razlogi se je največkrat pojavila zasnova nepretrganega proizvodnega procesa ter razne livarske in steklarske peči, ki jih ni mogoče ugašati in ponovno prižigati na dnevni ravni. Med organizacijske razloge smo uvrstili navedbe, ki se sklicujejo na hitro pokvarljivost izdelkov, nujnost priprave blaga za jutranjo opremo in sezonsko naravo prodaje proizvodov.

Ločeno od ostalih dejavnikov smo opravili tudi analizo stopenj avtomatizacije po posameznih aktivnostih. Na podlagi diagrama na sliki 4 lahko povzamemo, da so aktivnosti obdelave oz. proizvajanja $\mathrm{v}$ proizvodnih podjetjih $\mathrm{v}$ povprečju bolj avtomatizirane od ostalih in se kot edina skupina od petih preučevanih bolj nagibajo k avtomatizaciji kot ročni izvedbi. Na podlagi prikaza standardnega odklona lahko povzamemo tudi, da so bile ocene za omenjeno skupino aktivnosti precej manj razpršene od preostalih štirih skupin. Po povprečni stopnji avtomatizacije od najvišje do najnižje sledijo aktivnosti kontrole in vodenja, transport, skladiščenje in nazadnje zastoj. Za navedene aktivnosti se ocene v povprečju bolj nagibajo $\mathrm{k}$ ročni izvedbi, pri čemer je standardni odklon podatkov nekoliko večji, kar pomeni večjo razpršenost ocen. 


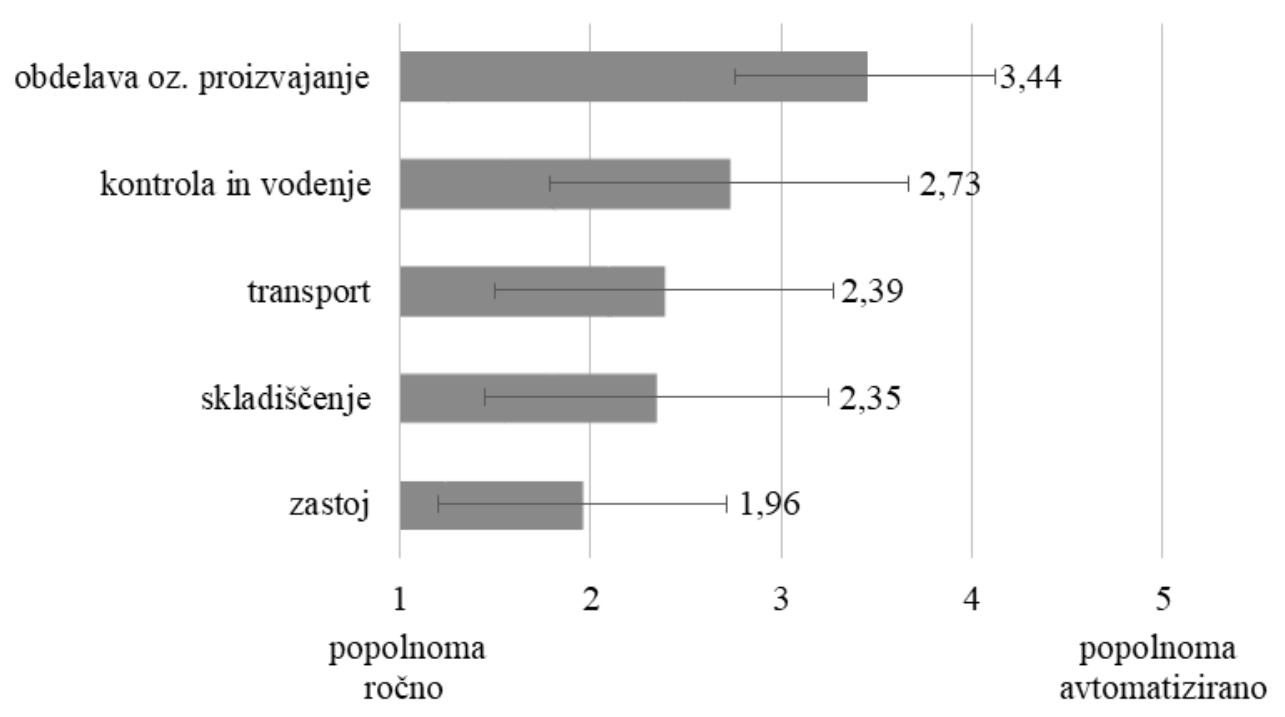

Slika 4. Stopnja avtomatizacije po vrstah aktivnosti $(\mathrm{n}=51)$

$\mathrm{V}$ nadaljevanju smo pod drobnogled vzeli naslednji merjen dejavnik v povezavi z aktivnostmi $\mathrm{v}$ proizvodnem sistemu, tj. obseg človekovega dela. To smo izvedli tako, da smo obseg dela $\mathrm{v}$ enoti človek/ura za vsako aktivnost na ravni posameznega anketiranca pretvorili v deleže. S pridobljenimi deleži smo nato za posamezno skupino aktivnosti izračunali povprečne deleže človekovega dela, kot je prikazano na diagramu na sliki 5 .

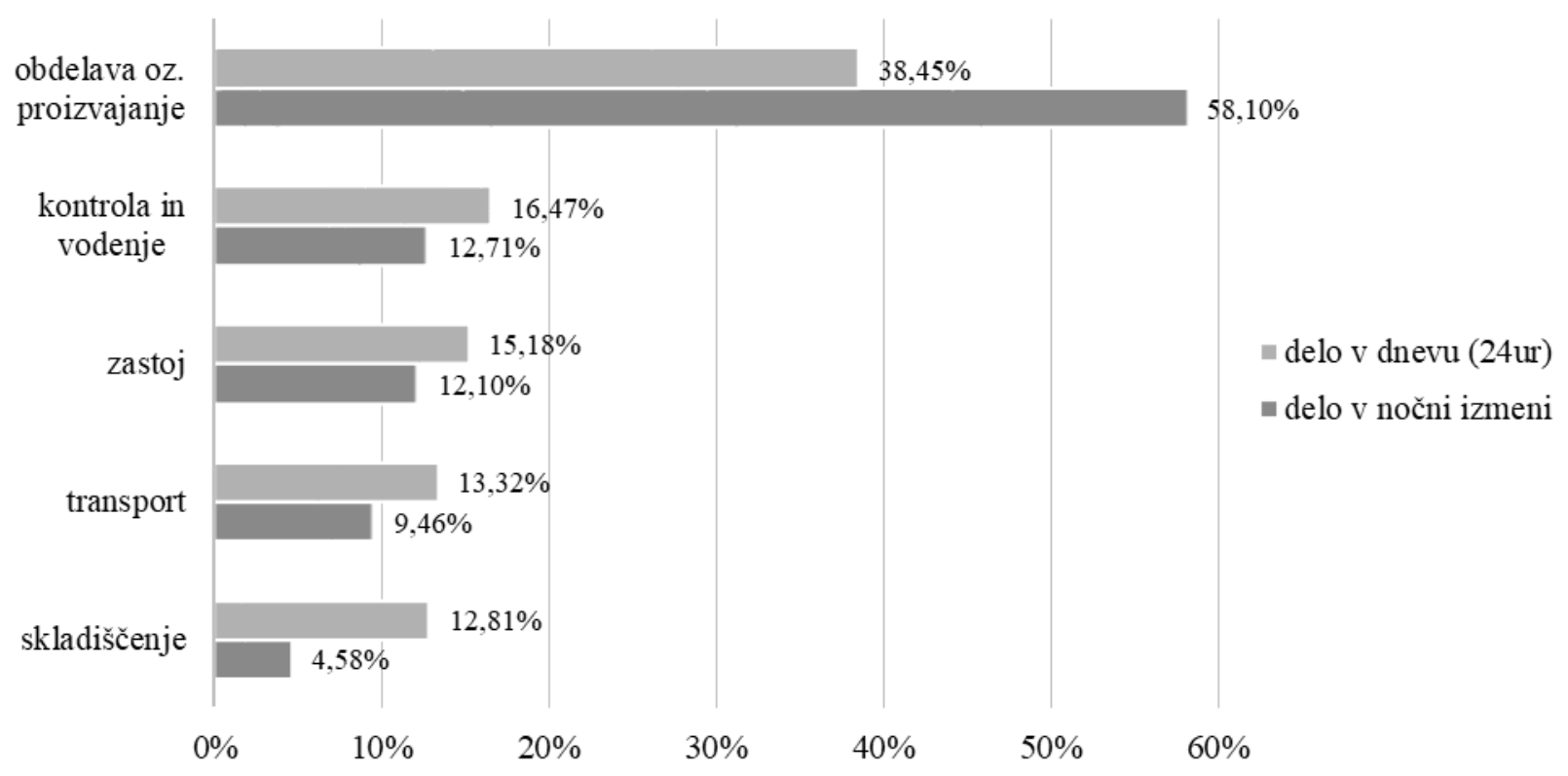

Slika 5. Obseg človekovega dela po aktivnostih $(\mathrm{n}=35)$

Ugotovimo lahko, da aktivnosti obdelave oz. proizvajanja v povprečju pomenijo bistveno več človekovega dela kot preostale štiri aktivnosti, medtem ko med slednjimi ni večjih razlik, saj se nahajajo v precej ozkem razponu. To še posebej pride do izraza, če upoštevamo le nočno delo, saj slednje pri aktivnostih obdelave oz. proizvajanja predstavlja kar dobro polovico 
vsega dela v nočni izmeni.

$\mathrm{Na}$ naslednjem diagramu so prikazane izračunane skupne ocene stopnje avtomatizacije posameznih proizvodnih sistemov, ki smo jih izračunali po lastni, predhodno predstavljeni metodologiji, $v$ povezavi $\mathrm{z}$ obsegom nočnega dela. $\mathrm{V}$ prikaz smo zajeli tudi t.i. nepopolne ocene, to so tiste, za katere smo prikazan izračun morali nekoliko prilagoditi. Nepopolne ocene smo pridobili z vprašalniki, ki niso bili izpolnjeni v celoti (npr. za eno od aktivnosti je kljub izpolnjenim količinam ur manjkal podatek o stopnji ali obratno - te aktivnosti smo izločili iz izračuna skupne ocene), ali pa so bile določene kombinacije odgovorov nelogične (npr. navedba določenega obsega človekovega dela kljub oceni, da gre za popolno avtomatizacijo; pri res popolnoma avtomatizirani izvedbi aktivnosti do potrebe po delu človeka praviloma ne bi smelo prihajati, zato smo pri ocenah stopnje $5 \mathrm{z}$ navedbo količine človekovega dela pri izračunu skupne ocene namesto 5 upoštevali 4,5, saj smo predpostavljali, da je anketiranec želel sporočiti, da gre kljub delu človeka za izredno visoko stopnjo avtomatizacije, za katero bi bila ocena 4 - pretežno avtomatizirano prenizka). Že po hitrem pregledu lahko sklepamo, da med preučevanima dejavnikoma ni povezanosti, saj so podatki razpršeni po celotnem polju in ni možno določiti smeri gibanja.

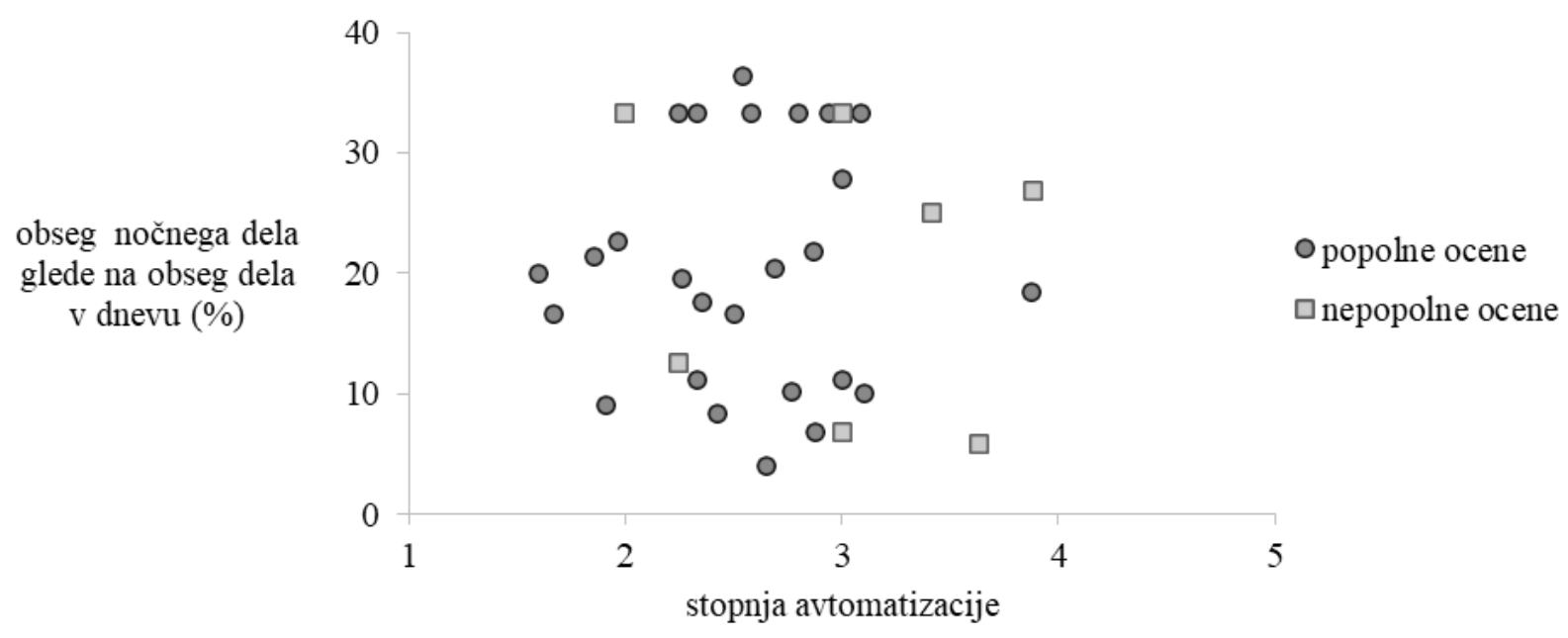

Slika 6. Stopnja avtomatizacije in obseg nočnega dela $(\mathrm{n}=34)$

Za potrditev naše domneve izračunamo še Pearsonov koeficient korelacije (r) tako za popolne kot vse ocene (popolne in nepopolne).

Tabela 1. Pearsonov koeficient korelacije stopnje avtomatizacije in nočnega dela

\begin{tabular}{ccc}
\hline & Popolne ocene & Vse ocene \\
\hline $\mathrm{n}$ & 27 & 34 \\
$\mathrm{r}$ & $-0,0124$ & $-0,0569$ \\
\hline
\end{tabular}

Pri obeh vrednostih koeficienta gre za negativen predznak, kar sicer nakazuje, da gre za negativno povezanost, vendar je treba pri Pearsonovem koeficientu korelacije upoštevati tudi 
vrednost koeficienta. $\mathrm{V}$ obeh primerih gre za izredno majhne absolutne vrednosti, kar pomeni neznatno povezanost.

Hipotezo, da med stopnjo avtomatizacije procesov proizvajanja in deležem ur proizvodnih delavcev, opravljenih v nočni izmeni, obstaja negativna povezanost (višja kot je stopnja avtomatizacije, manj je nočnega dela), torej zavrnemo.

\section{Zaključek}

Z empiričnim delom raziskave smo preučevali dve področji, stopnjo avtomatizacije procesov proizvajanja in obseg nočnega dela. $\mathrm{V}$ ta namen smo zasnovali in izvedli empirično raziskavo na populaciji 502 srednje velikih ali velikih slovenskih podjetij z registrirano predelovalno dejavnostjo in vsaj 50 zaposlenimi. Ugotovili smo, da večji del anketiranih podjetij v svojem proizvodnem sistemu izvaja nočno izmeno, razlogi zanjo pa so večinoma ekonomske narave. Sledijo jim razlogi tehnične narave, zelo malo pa jih je organizacijske narave. Glede na ocene stopnje avtomatizacije smo ugotovili, da so v povprečju najbolj avtomatizirane aktivnosti obdelave oz. proizvajanja, medtem ko so preostale aktivnosti, to so transport, skladiščenje, kontrola in vodenje ter zastoj, manj avtomatizirane. Hipotezo, in sicer da med stopnjo avtomatizacije procesov proizvajanja in obsegom nočnega dela obstaja negativna povezanost smo zavrnili.

Prispevek rezultatov iz naše raziskave k managerski znanosti in stroki je tako teoretičen kot empiričen, pa tudi praktičen. $V$ teoretičnem delu smo opravili pregled strokovne literature na temo managementa, managementa proizvajanja, avtomatizacije procesov proizvajanja ter pravnih in drugih vidikov nočnega dela. $\mathrm{Na}$ enem mestu smo zbrali in predstavili vsa dosedanja teoretična vedenja in empirična spoznanja, ki bodo v pomoč morebitnim drugim raziskovalcem te tematike $\mathrm{v}$ prihodnosti. $\mathrm{Z}$ empirično raziskavo smo prišli do novih znanj, ki jih doslej še ni bilo in predstavljajo novost na tem področju. Z izvirnimi ugotovitvami iz opravljenega anketiranja smo zavrnili predpostavko, da avtomatizacija procesov proizvajanja neposredno vpliva na obseg nočnega dela. Dodatno smo skozi predstavljeno literaturo ugotovili, da je nočno delo poslovno-organizacijski sistem, ki je podvržen različnim drugim dejavnikom in ga zato ni smiselno raziskovati zgolj $\mathrm{v}$ navezavi $\mathrm{z}$ avtomatizacijo procesov. Kot naš naslednji prispevek k managerski znanosti in stroki štejemo tudi metodologijo za merjenje stopnje avtomatizacije $\mathrm{v}$ proizvajanju, ki smo jo zasnovali $\mathrm{z}$ namenom načrtovanja raziskave in zbiranja podatkov. Pripravili smo tri priporočila za izboljšanje dane prakse na temo avtomatizacije in deleža ur nočnega dela. Priporočila za managersko prakso naj bi imela praktične implikacije za vse, ki se ukvarjajo z načrtovanjem, organiziranjem, vodenjem in kontroliranjem procesov proizvajanja v srednje velikih ali velikih slovenskih podjetjih.

Pri načrtovanju in izvedbi raziskave smo identificirali različne predpostavke. Predpostavljali smo, da stopnja avtomatizacije procesov proizvajanja kot dejavnik neposredno vpliva na obseg ur v nočni izmeni proizvodnih delavcev. Predpostavljali smo, da pet (5) predhodno 
definiranih operacij $\mathrm{v}$ okviru proizvodnega sistema tega celovito zajame in je ustrezen kazalnik oz. pokazatelj stopnje avtomatizacije omenjenega sistema. Predpostavljali smo tudi, da anketiranci razumejo, kaj pomeni posamezna $\mathrm{v}$ anketi splošno opredeljena operacija proizvajanja za njihov primer, in da bodo $\mathrm{v}$ skladu $\mathrm{s}$ tem na vprašanja odgovarjali konstruktivno. Pri načrtovanju in izvedbi raziskave smo identificirali različne omejitve. V okviru preučevanih dejavnikov smo se omejili na avtomatizacijo zgolj procesov proizvajanja, po drugi strani pa se bomo osredotočili na nočno delo le tistih delavcev, ki delo opravljajo v okviru proizvodnega sistema. Pri izbiri vzorca smo se omejili zgolj na podjetja, ki delujejo v okviru predelovalne dejavnosti na območju Slovenije in jih uvrščamo med srednja ali velika podjetja z najmanj 50 zaposlenimi. Rezultatov raziskave ne bo možno posplošiti na družbe v katerih opravljajo storitvene dejavnosti.

$\mathrm{V}$ prihodnjih raziskavah bi bilo smiselno preučiti, katere so sploh prednosti oz. pozitivni učinki avtomatizacije po mnenju in izkušnjah delodajalcev. S ciljem pridobitve boljšega vpogleda v potencialne razrešitve za omejevanje nočnega dela, bi bilo zato vsako nadaljnjo raziskavo smiselno zasnovati kot kvalitativno raziskavo s posameznim proizvodnim sistemom kot osnovno enoto raziskovanja. Raziskovanje avtomatizacije procesov proizvajanja in nočnega dela bi bilo koristno opraviti tudi v drugih dejavnostih, ki sicer niso proizvodno naravnane, a je kljub temu takšna oblika dela nujno potrebna in neizogibna, npr. v zdravstvu, trgovini, policiji, medijih, vojski ipd.

\section{Reference}

1. Ahlborg G., Axelsson, G. \& Bodin, L. (1996). Shift work, nitrous oxide exposure and subfertility among Swedish midwives. International journal of epidemiology, 25(4), 783-790.

2. Brann, D., Thurman, D. \& Mitchell, C. (1996). V Proceedings of the 3rd Annual Symposium on Human Interaction with Complex Systems, avgust 1996 (str. 276-283). Dayton, Ohio: Wright State University.

3. Chui, M., Manyika, J. \& Miremadi, M. (2015). Four fundamentals of workplace automation. McKinsey Quarterly, 29(3), 1-9.

4. Costa, G. (2004). Lavoro a turni e notturno. Firence: SEE-Firenze.

5. Dobrin, T. (1992). Delovna razmerja s krajšim delovnim časom. Podjetje in delo: revija za gospodarsko, delovno in socialno pravo, 2, 110-125.

6. Eddy, M. (2013). Checklist for Lights-Out Manufacturing. Pridobljeno na https://www.productionmachining.com/articles/checklist-for-lights-out-manufacturing

7. Fanuc. (2018). Automating the nightshift to meet growing production demands. Pridobljeno na: https://www.fanuc.eu/ /media/files/pdf/customer-case-pdfs/ customer\%20case\%20pdf_ntm_rz.pdf?la=en

8. Fasth, A, Stahre, J. \& Dencker, K. (2008). Measuring and analysing Levels of Automation in an assembly system. Manufacturing Systems and Technologies for the New Frontier. London, Springer.

9. Frohm, J. (2008). Levels of Automation in Production Systems (Doktorska disertacija). Chalmers 
University of Technology, Gothenburg.

10. Goranski, S. (2011). Stres pri delu medicinskih sester v UKC Maribor. Magistrsko delo, Maribor: Ekonomsko-poslovna fakulteta, Univerza v Mariboru.

11. Gorenjske elektrarne. (2014). Delna avtomatizacija hidroelektrarne Sava. Pridobljeno na https://www.gek.si/info/601200079/Delna_avtomatizacija_hidroelektrarne_Sava

12. Gvin.com. (2019). Napredni iskalnik. Pridobljeno na http://www.gvin.com/IskalnikCE/Pages/SearchResult.aspx?Mode=GvinSI\&App=GvinIskalnikSI $\&$ Kontekst=5\&Lang=sl-SI

13. Hundrič, J. (2017). Avtomatizacija namenskega obdelovalnega stroja z robotskim manipulatorjem in s strojnim vidom (Magistrsko delo). Univerza v Mariboru, Fakulteta za elektrotehniko, računalništvo in informatiko.

14. Kaltnekar, Z. (1996). Organizacija delovnih procesov. Kranj: Moderna organizacija v sestavu VŠOD Kranj.

15. Knauth, P., Eichhorn, B., Löwenthal, I., Gärtner, K. H. \& Rutenfranz, J. (1983). Reduction of nightwork by re-designing of shift-rotas. International archives of occupational and environmental health, 51(4), 371-379.

16. Knutsson, A. (2003). Health disorders of shift workers. Occupational medicine, 53(2), 103-108.

17. Korelič, T. (2017). Vpliv nočnega in izmenskega dela na motnje spanja med izvajalci zdravstvene nege (Magistrsko delo). Univerza v Mariboru, Fakulteta za zdravstvene vede.

18. Ljubič, T. (2000). Planiranje in vodenje proizvodnje. Ljubljana: Založba Moderna organizacija v okviru FOV.

19. Löfving, M., Almström, P., Jarebrant, C., Wadman, B. \& Widfeldt, M. (2018). Evaluation of flexible automation for small batch production. Procedia Manufacturing, 25, 177-184.

20. Manyika, J., Chui, M., Miremadi, M., Bughin, J., George, K., Willmott, P. \& Dewhurst, M. (2017). Harnessing automation for a future that works. Pridobljeno na: http://pinguet.free.fr/futuwork--.pdf

21. Mengeot, M. (2009). Proizvodnja in razmnoževanje: kraja zdravja prihodnjim generacijam. Ljubljana: Zveza svobodnih sindikatov Slovenije.

22. New York Post. (2018). These construction robots work the night shift. Pridobljeno na https://nypost.com/2018/04/23/these-construction-robots-work-the-night-shift/

23. Noël, M, Sodhi, M. \& Lamond, B. (2007). Tool planning for a lights-out machining system. Journal of Manufacturing Systems, 26(3-4), 161-166.

24. Novak, A. (2016). Usklajevanje delovnega in zasebnega življenja v Sloveniji (Magistrsko delo). Univerza v Ljubljani, Fakulteta za družbene vede.

25. Parasuraman, R. \& Riley, V. 1997. Humans and automation: Use, misuse, disuse, abuse. Human factors, 39(2), 230-253.

26. Pustovrh, T. (2015). Vplivi novih tehnologij na spreminjanje delovnega okolja in zaposlenih. Pridobljeno na http://www.osha.mddsz.gov.si/resources/files/Pustovrh-03Spreminajnje_delovnega_okolja.pdf

27. Rotman, D. (2013). How Technology Is Destroying Jobs. Technology Review, 16(4), 28-35.

28. Scott, A. \& LaDou, J. (1994). Health and safety in shift workers. Occupational medicine, 3: 960 986.

29. Sever, K. (2011). Posodobitev proizvodne linije v podjetju Iskra Avtoelektrika (Magistrsko delo). Univerza v Novi Gorici, Poslovno-tehniška fakulteta.

30. Sheridan, T in Verplanck, W. L. (1978). Human and computer control of undersea teleoperators. 
Cambridge: Massachusetts Institute of Technology.

31. Straif, K, Baan, R., Grosse, Y., Secretan, B., El Ghissassi, F., Bouvard, V., Altieri, A., BenbrahimTallaa L. \& Cogliano, V. (2007). Carcinogenicity of shift-work, painting, and fire-fighting. The lancet oncology, 8(12), 1065-1066.

32. Šuman, V. (2016). Analiza, prenova in predlog avtomatizacije proizvodnega procesa v podjetju Letina inox (Magistrsko delo). Univerza v Mariboru, Fakulteta za elektrotehniko, računalništvo in informatiko.

33. Thierry, H. (1981). Compensation for shiftwork: a model and some results. V W. Š. Colquhoun, \& J. Rutenfranz (ur.), Studies of shiftwork (str. 449-462). London: Taylor \& Francis.

34. Tsukidate, A. (2018). Nagoya hospital to use robots for deliveries of drugs, materials. The Asahi Shimbun. Pridobljeno na http://www.asahi.com/ajw/articles/AJ201801010027.html

35. Vetter,T. (2015). Pravne podlage za organizacijo dela za tehnike/tehtnice zdravstvene nege (Magistrsko delo). Univerza v Mariboru, Fakulteta za zdravstvene vede.

36. Vimpolšek, M. (2016). Analiza osnov konkurenčnih prednosti z namenom optimizacije procesov v izbranem farmacevtskem podjetju (Magistrsko delo). Univerza v Ljubljani, Ekonomska fakulteta.

37. Vrčkovnik, A. (2008). Uporaba metodologije Šest sigma vitke proizvodnje v oskrbovalni verigi (Magistrsko delo). Univerza v Ljubljani, Ekonomska fakulteta.

38. Wolfgang, M., Lukic, V., Sander, A., Martin, J. \& Küpper, D. (2017). Gaining robotics advantage. Pridobljeno na http://image-src.bcg.com/Images/BCG-Gaining-Robotics-AdvantageJune-2017_2_tcm96-161882.pdf

39. Zakon o delovnih razmerjih (ZDR-1). (2013, 13. Marec). Uradni list RS, št. 21/2013. Pridobljeno na http://www.pisrs.si/Pis.web/pregledPredpisa?id=ZAKO5944

Urška Kosem je leta 2016 zaključila dodiplomski študij za naziv diplomirana ekonomistka na Fakulteti za Management v Kopru, kjer je nadaljevala tudi podiplomski študij na programu inoviranje in podjetništvo. Tekom študija se je zaposlila na Triglav, Zdravstveni zavarovalnici, v času zaposlitve pa so jo pričele zanimati tematike $\mathrm{v}$ povezavi $\mathrm{z}$ zdravjem in dobrobitom človeka. Slednjih se je posredno dotaknila tudi $\mathrm{v}$ magistrskem delu, $\mathrm{V}$ katerem je raziskovala potencial avtomatizacije za omejitev nočnega dela in s tem povezanih negativnih vplivov na človeka, s čimer je v letu 2019 zaključila magistrski študij ter pridobila naziv magistrica inoviranja in podjetništva.

Mirko Markič je doktoriral na Fakulteti za organizacijske vede Univerze v Mariboru s področja organizacijskih ved na temo inoviranja. Po dvanajstih letih delovanja v gospodarstvu se je zaposlil na Fakulteti za menedžment Univerze na Primorskem. Je redni profesor za področje menedžmenta in znanstveni svetnik ter vodja ali član 17 raziskovalnih projektov in projektov z gospodarstvom. Njegova bibliografija obsega več kot 630 enot s področja upravnih in organizacijskih ved ter javnega zdravstva (varstvo pri delu).

\section{Abstract: \\ Automation of Manufacturing Processes and Night Work}

Research Question (RQ): What is the correlation between the level of automation of manufacturing processes and the amount of night work?

Purpose: The purpose is to carry out an empirical study on the level of automation of manufacturing processes in larger Slovenian manufacturing companies and the amount of night work carried out by production workers and to determine whether a higher level of 
automation signifies a smaller amount of night work or to determine whether there is any statistically significant correlation between the said factors.

Method: A quantitative survey was conducted on a sample of 116 medium-sized or large Slovenian manufacturing companies with at least 50 employees, to evaluate the level of automation of the entire production system through five groups of activities that occur within the production process. We compared the number of man-hours of production workers carried out during the night shift to the number of man-hours of production workers carried out throughout the whole workday. The estimated level of automation of each production system was then paired with the share of night work in relation to all days' work, and the Pearson correlation coefficient was calculated.

Results: The calculated correlation is of negative value, which means that the higher the level of automation of the manufacturing processes, the smaller the amount of the night work, but the absolute value is too low to speak of a statistically significant correlation.

Organization: In relation to the automation of manufacturing processes, we have presented aspects and elements of automation that can help implement automation of manufacturing processes in an organization more effectively. In relation to night work, we have presented arguments as to why it makes sense for management to set a restriction on the amount of night work as a goal, and provide suggestions on how to pursue the said goal.

Society: The research considers the automation of production processes as a potential solution for eliminating or limiting the amount of night work, as well as all the negative effects of night work on both the worker - an individual and also on his or hers social circle. Based on the findings, we have made proposals that can help eliminate or limit night work and thus affect the organization of working time and the quality of working life of an individual.

Originality: The research addresses two substantively unrelated factors which have not yet had its potential correlation studied before.

Limitations / further research: Research cannot be generalized to service organizations, nor can it be generalized to activities in manufacturing companies that do not take place within the production system. Researches on the automation and night work would also be useful to undertake based on other activities that are not manufacturing oriented, yet is such a form of work still absolutely necessary and inevitable, e.g. in healthcare, trade, police, media, military, etc.

Keywords: management, automation, level of automation, manufacturing process, night work, night shift, companies, production, manufacturing industry, research.

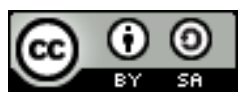

Creative Commons License

This work is licensed under a Creative Commons Attribution-ShareAlike 4.0 International License. 